\title{
The Role of Catalytic Collaboration in Leveraging Transformational Leadership Competencies to Generate Sustainable Innovation
}

\author{
Solikin M. Juhro ${ }^{1 *}$, A. Farid Aulia ${ }^{2}$, Donni Hadiwaluyo ${ }^{3}$, Dessy Aliandrina ${ }^{4}$, Edo Lavika ${ }^{5}$ \\ 1,2,3,4,5 Bank Indonesia Institute, Bank Indonesia, Jakarta, Indonesia
}

\section{Keywords:}

Transformational Leadership,

Catalytic Collaboration,

Sustainable Innovation

Matrix, Leadership Model,

Leadership Competencies

\section{Received}

06 July 2020

Received in revised form

22 July 2020

Accepted

22 July 2020

\begin{abstract}
We analyze the impact of a catalytic collaboration as a tool on the leverage of transformational leadership competencies to generate a sustainable innovation by developing a Sustainable Innovation Matrix (SIM) leadership model. We observe it by employing a unique data set of the behaviors of fifty regional heads (mayors and regents) in Indonesia. The results of the analysis show that the transformational leaders who made a catalytic collaboration have proven ability to create significant impacts on their regions. The changing times in the industry 4.0 era are a great opportunity for a leader to formulate a program involving various parties. Various sources of information can easily be accessed; moreover, it becomes faster and more efficient to communicate with others. The leaders with good transformational leadership competencies who make a catalytic collaboration can generate innovations that not only create relevant impacts on the needs of their regions, but they are also sustainable in terms of economic and environmental aspects. The results also suggested that leaders must be courageous to make innovation and strongly care for their regional development despite limited resources there. In doing so, those leaders must collaborate catalytically with other parties to optimize all available opportunities for the progress of the regions that they lead.
\end{abstract}




\section{Introduction}

In this digital era, the world is entering a hyperconnected world phase (World Economic Forum, 2013), where the people and things around us are getting more and more connected to the network and information transparency, collaborating beyond borders, and obtaining content-heavy horizons from abundant data availability. Not only does the digital era generate development towards better changes, but it also creates typical problems such as individualism and the silo problems (Tett, 2015). A silo is a mindset generated when a certain department or sector does not want to share its information with other people at the same company (Business Directory, 2017; Tett, 2015). A silo takes place when a team shares a general task, but based on their group's power and status. They are reluctant to share their resources with another department and tend to solve a problem with a solution that they have developed by their won. In fact, various problems that they are facing are often related to another department's performance and problems (Shift Indonesia, 2014). Therefore, the silo caused by the advancement of the Industrial Revolution 4.0 era poses a challenge.

In Indonesia, the government's main strategies are developing a healthy and sustainable digital ecosystem to be effective and to be able to move all economic sectors (Dhahir, 2019). Problems arising in the regions such as regional economic gaps due to unevenly-disseminated technology make it difficult for Indonesia to realize. Moreover, other problems pose a challenge such as inadequate digital infrastructures and non-optimal digital platforms. Manpower less qualified to facing technological changes is also an important factor (Hadiyat, 2014). To face those challenges, we should take advantage of technological advancement and industries must be oriented to enhanced effectiveness and efficiency.

Since the future is full of uncertainties, a leader must possess some unique competencies. The transformational leader must be able to design a policy, able to solve a problem, able to influence, have a visionary viewpoint, be agile, have a breakthrough, and possess emotional and social intelligence (Juhro \& Aulia, 2018; Edison et al., 2019). When the leader owns those competencies, they can answer various challenges with various breakthroughs to create new sources of growth (Juhro \& Aulia, 2019).

Nowadays, it is very difficult to solve those global complexities individually (per silo). Collaboration is required to solve those problems. Collaboration is defined as a mutual engagement among parties materialized in the forms of a coordinated effort aimed at solving the shared problems (Lai, 2011). This collaborative interaction has several components such as shared goals, the symmetric structure, a high level of negotiation, and interdependence, so it is expected to be able to generate ideas and innovations to become a driving force to be more developed. A leader must employ more comprehensive approaches to face complex challenges. A catalytic collaboration is a new approach employed to create a social and economic transformation that can help various organizations to work together for a much greater goal than each of the organization's goal.

The catalytic collaboration observation context and the scope of transformational leadership are generalized on public leadership in Indonesia based on two basic considerations. First, in terms of its regions, Indonesia consists of 34 provinces and 500 regencies and cities, with regional autonomy. The regional head plays an important role in an effort to unite variables of economic growths in the regions to support national development. Second, the regional head 
is an independent policy maker, whether to collaborate to solve problems of silos in implementing a policy or not.

This study aimed to explore transformational leadership-related issues and a catalytic collaboration as new powerful approaches employed to anticipate more complex globalization challenges. This study also elaborates on how a transformational leader plays an important role in anticipating complex globalization challenges in the digital era, so it can generate transformational and sustainable breakthrough innovation.

To conclude, the significance of this research is that traditional collaboration that is only based on momentary relationships can no longer be maintained in a time when the problem faced is a complex problem that requires long-term handling. So, it requires a type of collaboration that lasts long. In terms of novelty, this research proposes the Sustainable Innovation Matrix model as a tool to categorize leaders in four categories of areas from areas that are less productive and not sustainable to highly productive and sustainable areas.

This paper consists of five chapters. After the introduction, chapter two discusses the theoretical background and thoughts regarding the relationships between Transformational Leadership and catalytic collaboration, and the proposed propositions. Chapter three elaborates on the methodology where we specifically propose a leadership model to observe how a leader plays his role in encouraging a sustainable innovation, namely Sustainable Innovation Matrix (SIM). Chapter four elaborates on the analysis results of the behaviors of several Indonesian regional heads based on the proposed SIM model. Chapter five presents the conclusion and implication.

\section{Theoretical Background}

\section{The Urgency of Transformational Leadership and Collaboration (Why)}

Along with the complexity, challenges and changes globally taking place, a leader capable of helping his organization survive and achieve the sustainable development goals will become more highly demanded. Transformational leadership is deemed to be appropriate when applied in this more complex era, since it is a kind of participative leadership. The leader, together with the followers, moves towards the shared mission. In fact, in this TUNA (Turbulence, Uncertainty, Novelty, and Ambiguity) era, an organization needs a flexible and adaptive leader since the world is changing very rapidly (Juhro, 2019). The leader must continuously learn and renew his organizational vision and strategies in order not to be left behind the progress of the age. Only transformational leaders are flexible and adaptable leaders.

To be able to make an organizational transformation, a leader surely has to possess several basic competencies. These competencies are grouped into three clusters as previously having been proposed by Goleman and Senge (2014), namely inner, others, and outer clusters known as the triple focus. These three transformational leadership competency clusters are then developed into nine competencies that a transformational leader must possess, namely (i) visionary, (ii) breakthrough, (iii) agility, (iv) emotional intelligence, (v) social intelligence, (vi) ability to influence others, (vii) ability to communicate, (viii) ability to solve a problem, and (ix) ability to make a decision (Juhro \& Aulia, 2018).

Transformational leadership is a kind of leadership that inspires and encourages the followers as well as members of the society to determine a great goal and to achieve it together. In terms to its focus on influencing other people, there are four levels of relationships between 
a leader and his followers in transformational leadership, namely professionally, personally, emotionally, and intellectually. These four levels of relationships between a leader and his followers will determine the followers' transformational effectiveness (Maalouf, 2018).

Meanwhile, collaboration is a mutual engagement among several participants in their coordinated effort, aimed at solving a problem together (Lai, 2011). This collaborative interaction is characterized by shared and common goals, symmetric structures, a high level of negotiation, interactivity, and interdependence. Roschelle (1992, as cited in Lai, 2011) mentions that collaboration is required to develop understanding through sharing ideas and information among various parties, and proposing a solution mechanism to an uncertainty. Boyer-Kassem et al. (2017) mentioned reasons why collaboration was important, such as (i) it made every member of the team able to cooperate to achieve their shared and common goals by thinking, brainstorming, and offering different perspectives to find a solution; (ii) it generated a strong meaning of a goal; (iii) it provided an opportunity for every member of the team to participate, communicate their ideas, and learn from one another; and (iv) it challenged each member to analyze themselves such as thinking, applying, and feeling the clarity of their own competencies.

Eckert (2017) stated that a study conducted to various technological industry-based corporation in Silicon Valley revealed that a collaboration was a key factor that could encourage innovation. In an innovation generation process, an inter-discipline collaboration enables the innovators to create their new, radical ideas that have never crossed anyone's mind before. Collaboration is one of the driving forces for the innovators to think out of the box since without any other people's thought challenge, the innovator will so easily be trapped into an undeveloped thought.

In a broader scope, the urgency to collaborate emerges in the contexts of supporting a sustainable development serving as the world's important at this moment through the launching of Sustainable Development Goals (SDGs) program. SDGs can effectively be materialized when various parties are willing to collaborate with one another to realize its 17 goals. In this regard, achieving development goals in SDGs era requires multi-party partnership especially to answer the trans-pillar goals and indicators. The necessity of collaboration is also one of the SDGs points (point 17), namely partnership to achieve goals. ${ }^{1}$

\section{A Catalytic Collaboration Beyond Standard Collaboration (What)}

Old approaches of collaboration become more ineffective when applied amidst the higher world's complexity magnitude. Problem solution through a silo will make an organization/society more left behind from the world civilization speeding up faster and unstoppably (Tett, 2015). A mere, standard (traditional) collaboration is deemed to not be able to solve complexity of the global challenge nowadays. The type of collaboration required in the future is a collaboration employed not only to achieve its goals, but also to be able to

\footnotetext{
${ }^{1}$ The goals are no poverty; no starvation; healthy and prosperous life; quality education; gender equality; clean water and decent sanitation; clean and affordable; decent job and economic growth; industry, innovation, and infrastructure; smaller gap; sustainable city and residence; responsible consumption and production; climate change handling; ocean ecosystem; land ecosystem; strong peace, justice and institution; and partnership to achieve the goal. For more details, please go to the official website of Sustainable Development Goals (SDGs) UN (https://sustainabledevelopment.un.org/).
} 
maintain the sustainability of results previously achieved and to be able to more positively impact on future development. Therefore, a catalytic collaboration approach will become more relevant to serve as one of the tools for leaders.

A catalytic collaboration is a new approach employed to create a social and economic transformation that can help various organizations work together to achieve a far greater goal than each of the organizations' goal (Zohdy et al., 2016). A catalytic collaboration has a relatively bigger potential (than other old approaches) in answering global challenges. For instance, it is mentioned that a catalytic collaboration has a potential to unite magnitudes of economic growths taking place in the regions, so the national and even global economic growths will become better. Moreover, a study conducted by Zohdy et al. (2016) revealed that the impact generated by a catalytic collaboration was a long-term and sustainable impact and also had a great potential to solve many complex social problems.

\section{A Catalytic Collaboration as a Tool to Develop Transformational Leadership (How)}

Transformational leaders have an opportunity to be the answer to the world by becoming reformers in various fields through innovation taking advantage of constraints (frugal innovation). It is a type of leadership making changes by employing innovations in order to create impacts and create sustainable prosperity (Juhro \& Aulia, 2019). Due to future uncertainties, a leader must possess competencies to tackle future uncertainties and environmental upheavals. Those competencies are ability to make a policy, ability to solve a problem, ability to influence, ability to communicate, visionary, agile, new breakthrough, emotional intelligence, and social intelligence (Juhro \& Aulia, 2018).

By possessing those competencies, a leader is expected to answer the challenges by creating a new breakthrough and has to build and strengthen collaboration to create a sustainable innovation. When applied, a catalytic collaboration has four main components (Zohdy et al., 2016), namely prioritizing learning, systems thinking and action, democratizing access to assets, and building long-term, diverse, and transformational relationships.

The first component is prioritizing learning. This component focuses on a leader's (catalytic collaborator's) ability to identify relevant strategies to overcome social and economic problems. Prioritizing learning also stresses on knowledge sharing among the organizations/societies. Moreover, organizations and societies are expected to be transparent, to nurture good interpersonal relationships among one another, and trusting one another in that pertinent hub. Some companies are trying to trigger that behavior, for instance, Google's policy of $20 \%$ time, leaving a day a week free for employees to learn, collaborate, and work on their own projects. Learning to become relevant-strategic leaders happens by intentionally making priority on learning (Riemer, Schelhammer, \& Meinert, 2019).

The next component is applying systems thinking and action. Different networks in various organizations in a hub will increase their opportunity to see their challenges and chances with different perspectives, and this situation is expected to make the leader's action and decision regarding an issue more effectively. Watson-Manheim, Chudoba, and Crowston (2012) suggest that one of the significant challenges in wide range collaboration are boundaries, like time zones or national borders, that are unchanging. The effects of boundaries on the performance of collaboration team may differ and change over time. Joint team must be aware and adapted. This can be done by implementing a system thinking and action. 
The following component is democratizing access to assets. Opening access to the shared and common resources is an important thing to do to collaborate in a hub. The leaders are expected to create networks to be able to be connect and, to some certain extent, share things. Furthermore, along with technological advancement, the leaders are expected to be able to ensure that this access is capable of creating or taking advantage of technology and open space platforms. In the health sector, for instance, big data analytics is expected to have a transformative effect, such as how healthcare is delivered and consumed, the management of health services, and the health research (Raghupathi \& Raghupathi, 2014). These outcomes require collaboration among stakeholders in the health data ecosystem (Vayena, Dzenowagis, \& Langfeld, 2016) that require democratize assets and share beyond the organizational boundaries.

The last component is building long-term, diverse, and transformational relationships. The ultimate goal of this thing is to build transformational relationships among various policymakers, so, eventually, the collaboration that is formed will touch the sustainability component. Building long-term, diverse, and transformational relationships require trust (Vanneste, 2016; Zaheer \& Harris 2006; Zucker; 1987). Trusted process-based activities will develop long-term, largely stable relationships wherein each partner holds the view that the other partner would continue to behave as it had done in the past. Simply put, repeated interaction creates conditions for the development of trust (Gulati \& Sytch, 2008; Zaheer \& Harris 2006).

\section{Hypotheses}

Based on transformational leadership competencies proposed by Juhro and Aulia (2018) and based on the opinion of Zohdy et al. (2016) on the characteristics of a catalytic collaboration, we can make hypotheses as follows:

Hypothesis 1: There are two-way relationships between the transformational leadership competencies and catalytic collaboration behaviors.

It is predicted that all of the transformational leadership competencies may encourage the emergence of a catalytic collaboration. On the other hand, it is also predicted that a catalytic collaboration may leverage the transformational leadership competencies. Therefore, a more effective and sustainable transformation will be achieved. This sustainable transformation will be the ultimate goal that the leader wants to achieve. Figure 1 shows the interconnection between them. 


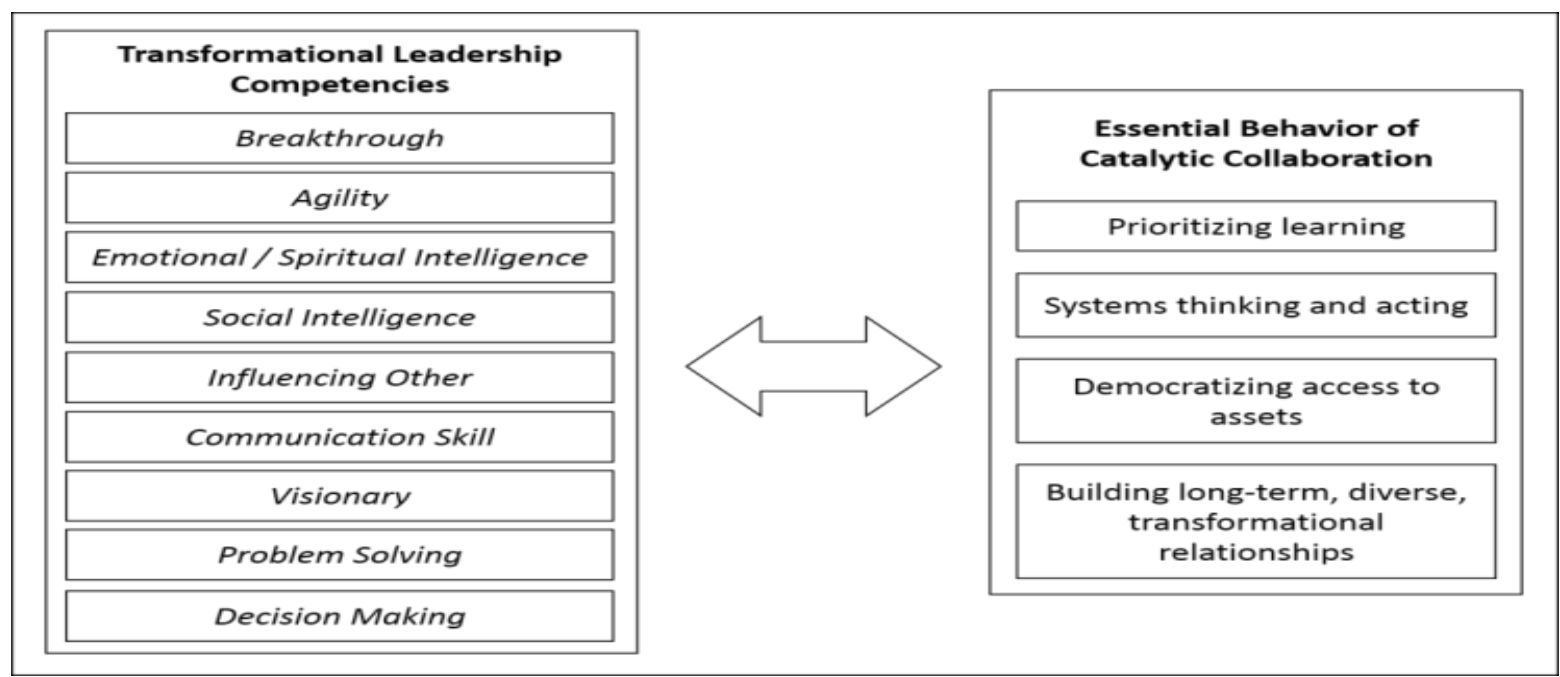

Figure 1. Interconnection between the transformational leadership competencies and catalytic collaboration.

Hypothesis 2: Catalytic collaboration behaviors support the transformational leadership competencies in creating a sustainable innovation.

In the Industrial Revolution 4.0 era, more complex problems require the leader's enhanced capacity more than just being a transformational leader. In general, traditional collaboration may solve problems of silos in an organization; however, it cannot solve sustainability problems. It is expected that these catalytic collaboration behaviors can leverage the transformational leadership competencies. With the support of a catalytic collaboration, it is expected that it will be able to generate an innovation in order to achieve its ultimate goal namely sustainable development. In this context, there is positive feedback from strengthened transformational leadership to catalytic collaboration behaviors.

To summarize, the transformational leadership will be looking for collaboration, then the collaboration will enhance transformational leadership competencies, and this will strengthen the leader's will to seek more collaboration at the broader level. This cycle will continue to reform, so that a culture of learning, a culture of thinking and acting systems, a culture of sharing assets, and a long-term relationship emerge. All of this will result in innovative problem solving, policy, and decision making, with a very broad and sustainable impact (Figure 2).

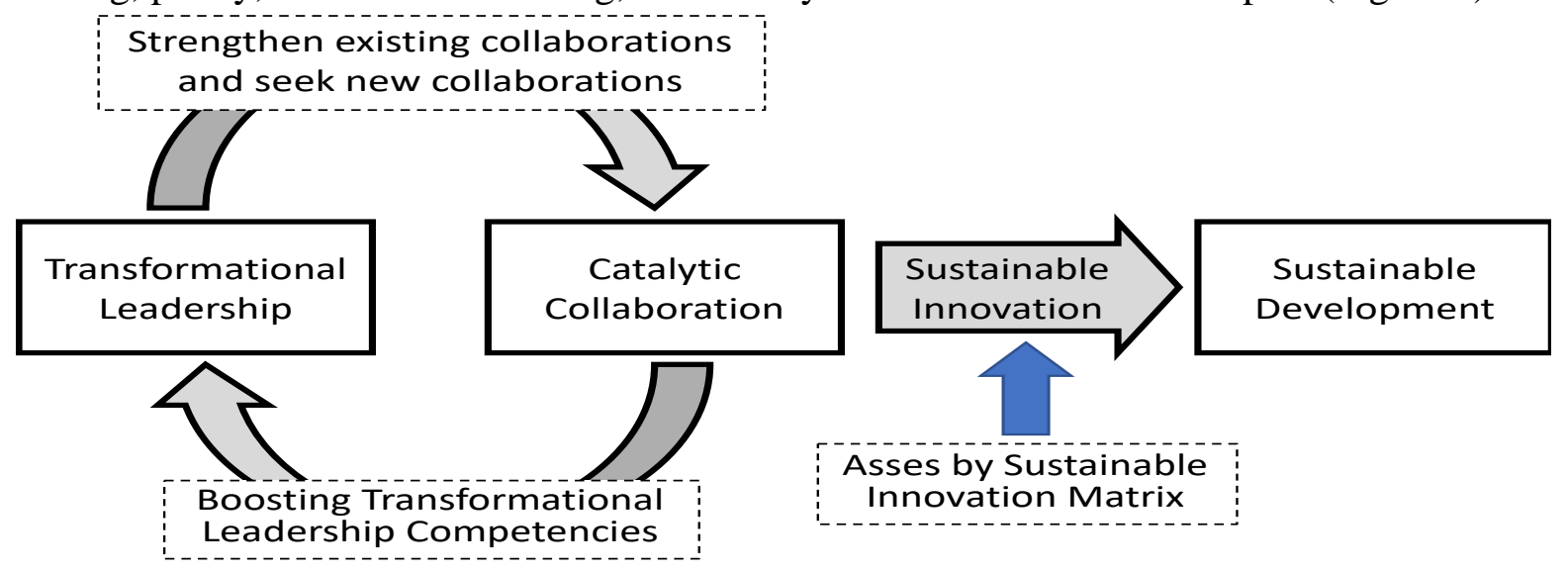

Figure 2. The cyclical relationship between transformational leadership and catalytic collaboration, and sustainable innovation. 


\section{Method}

The approaches employed in this study are literature study, hypothesis development, discussions with experts, data collection, and collaborative case studies to propose Sustainable Innovation Matrix.

\section{Sample and Characteristics}

\section{Participants and Scope of Leadership Behaviors}

The participants are 50 regional heads who participated in the Economic Leadership for Regional Government Leaders (REL) development program held by Bank Indonesia Institute (2018), as well as several other regional heads in accordance with the sampling criteria. ${ }^{2}$ Participants of the study are selected based on the timeframe in accordance with the context of the Industrial Revolution 4.0 era. We will analyze on the heads and programs that they conducted. Aspects to be observed are transformational leadership competencies and catalytic collaboration components shown through how they solved any problems in their regions. Moreover, the indicators of TL competencies were considered from Juhro and Aulia's (2018), namely (i) visionary, (ii) breakthrough, (iii) agility, (iv) emotional intelligence, (v) social intelligence, (vi) ability to influence others, (vii) ability to communicate, (viii) ability to solve a problem, and (ix) ability to make a decision. Meanwhile, the indicators of CC components were adopted from Zohdy et al.'s (2016) namely (i) prioritizing learning, (ii) systems thinking and action, (iii) democratizing access to assets, and (iv) building long-term, diverse, and transformational relationships.

The innovation dimensions are observed by considering several examples of the regional heads' performances in Indonesia who have generated measurable innovations (from the scalability and relevance aspects), in line with transformational leadership competencies and catalytic collaboration components that they possess. Specifically, we will observe whether the development focus of their region promotes a collaboration with various parties (not individual) so that innovation that they make in implementing their development program can run comprehensively and sustainably, reflected in the achievement indicators of their economic development goals in line with Sustainable Development Goals (SDGs) general criteria. In this regard, the goals refer to several economic and social indicators such as economic growth, inflation, and the regional unemployment rate, and/or other awards that the regional government received.

\section{Instrument}

\section{Proposed Model Sustainable Innovation Matrix}

This study examines a social reality based on the constructed proposition stating that a catalytic collaboration can leverage the transformational leadership competencies to achieve sustainable

\footnotetext{
${ }^{2}$ Economic Leadership for Regional Government Leaders (REL) is a Flagship Program held by Bank Indonesia Institute. This learning platform for the regional heads and regional legislators is formulated to enhance the participants' understanding on the latest issues, national and global challenges, industry 4.0, and experience sharing among the participants regarding policy formulations that have been implemented. This process will encourage an exchange of ideas and coordination among the participants. For more details, please see the Proceedings of Economic Leadership for Regional Government Leaders, Batch IV (Bank Indonesia Institute, 2018).
} 
innovation. We can see this social reality through several phenomena such as a catalytic collaboration that a transformational leader makes in their individual and organizational levels.

This study develops a new leadership model, namely Sustainable Innovation Matrix (SIM), to answer the question of whether a catalytic collaboration (CC) as a leadership tool can leverage the transformational leadership (TL) competencies in generating a sustainable innovation. It elaborates two innovation dimensions, namely scalability and the relevance. Leaders are expected to encourage an innovation that not only has a great impact and relevance to the region that they lead but also has a sustainable result in terms of economic and environmental aspects.

Therefore, SIM integrates the leadership dimensions, namely TL competencies and CC components and innovational impact dimension, namely scalability and relevance on the other side. A leader whose TL competencies and CC components are excellent will more easily achieve sustainable innovation. Meanwhile, an innovation that has a greater and more relevant impacts will become more sustainable. Hypothetically, the relations between the leadership dimensions and impacts of innovation tend to positively create sustainable innovation.

Therefore, a leader's characteristics in SIM can be categorized into 4 (four) areas.

Area I represents a leader's characteristics with a low level of transformational leadership and also a low level of catalytic collaboration. The leader has insignificant and irrelevant program results, and therefore unsustainable.

Area II represents a leader's characteristics with a relatively low level of transformational leadership and a relatively high level of catalytic collaboration, so the programs conducted are not so relevant and sustainable although they make a significant impact.

Area III represents a leader's characteristics with a relatively high level of transformational leadership and a relatively low level of catalytic collaboration, although the programs conducted are relatively highly relevant, they make a relatively low impact, they are not too sustainable.

Area IV represents a leader's characteristics with high levels of transformational leadership and catalytic collaboration, so the conducted programs are very significant and very relevant, and therefore sustainable. This area is ideally desired to encourage sustainable development.

The matrix in Figure 3 shows those behaviors.

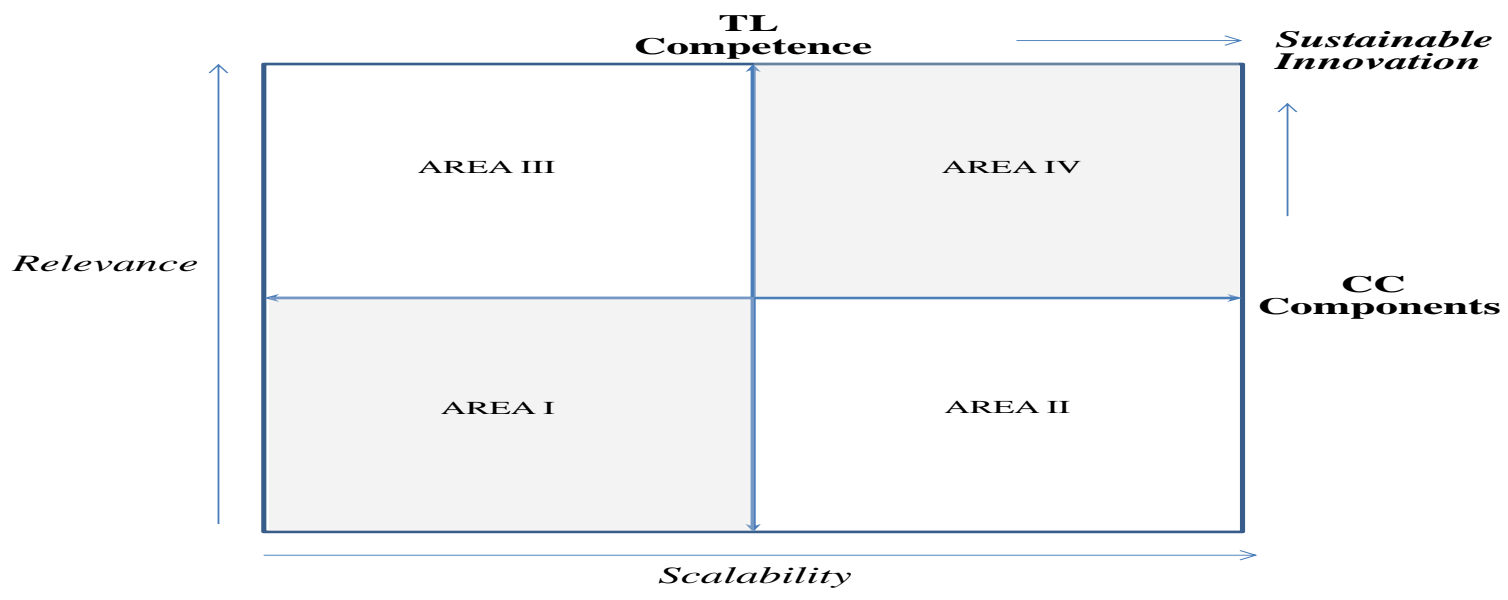

Figure 3. Sustainable Innovation Matrix (SIM) 
Transformational leadership competencies and catalytic collaboration components interconnect one another, so they strengthen one another. Leaders who can apply a catalytic collaboration well tend to leverage their transformational leadership competencies. Likewise, leaders with good transformational leadership competencies are expected to be able to sharpen their leadership potential to be able to make a catalytic collaboration. If applied by a regional head, those two things will generate an innovation and breakthrough for the region that create a quite significant impact, so they will help create new sources of economic growth both in the regional and the national levels.

\section{Analysis}

In this study, we analyzed several aspects. First, we analyzed transformational leadership competencies referring to nine transformational leadership competencies proposed by Juhro and Aulia (2018). Second, we analyzed a catalytic collaboration referring to $\mathrm{f}$ catalytic collaboration components proposed by Zohdy et al. (2016). Finally, we analyzed the achievement performance aspect of development goals as elaborated in the previous chapter. Table 1 (Appendix) shows the data.

Based on the collected data, we score the transformational leadership and catalytic collaboration aspects with 0 and 1 . Below is the distribution figure of transformational leadership competencies and catalytic collaboration components of 50 regional heads in Indonesia.

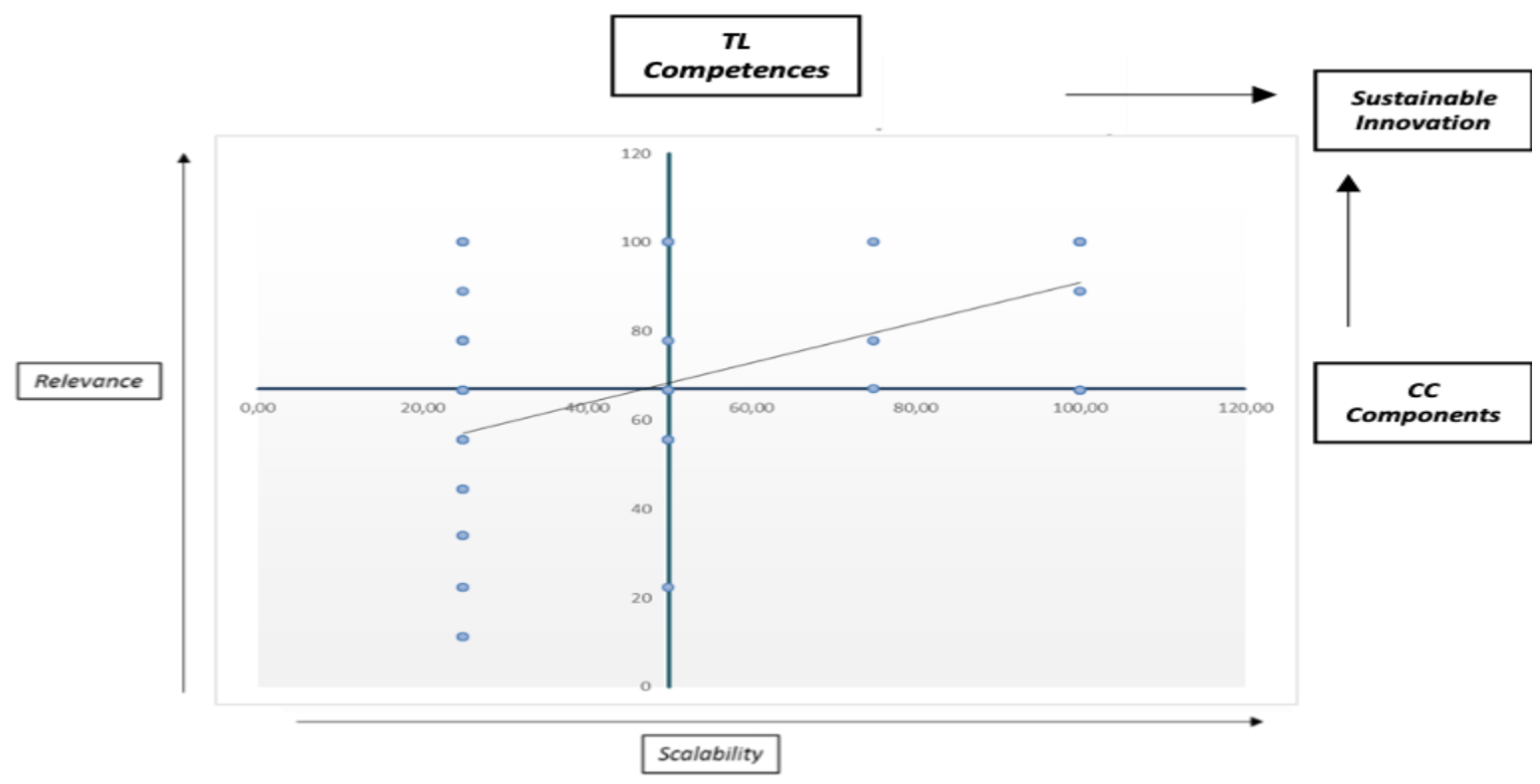

Figure 4. 2 Matrix of relations between transformational leadership and a catalytic collaboration

The distribution on the matrix shows that there are 14 regional heads in Area I (irrelevant and unsustainable), namely leaders with low transformational leadership and catalytic collaboration scores / below the median. Then, in Area II (irrelevant but sustainable) there are five regional heads, namely leaders with low transformational leadership scores but with high catalytic collaboration score. In Area III (relevant but unsustainable), there are 13 regional heads, namely leaders with high transformational leadership scores but low catalytic collaboration score. Finally, there are 18 regional heads already in the ideal condition, Area IV 
(relevant and sustainable), namely leaders with high transformational leadership and catalytic collaboration score.

The regional heads in Area I are samples of regional heads 5, 11, 13, 14, 15, 19, 21, 22 , 25, 27, 29, 31, 41, and 47. The regional heads in Area II are samples of regional heads 9, 12, 18, 23, 48. The regional heads in Area III are samples of regional heads 1, 20, 24, 26, 28, 30, $32,33,34,36,38,43$, and 45. Meanwhile, the regional heads in the ideal condition / Area IV are samples of regional heads $2,3,4,6,7,8,10,16,17,35,37,39,40,42,44,46,49$, and 50.

\section{Result}

From the distribution above, the following conclusion was drawn. First, most of the regional heads are not in the ideal area, Area IV, with a high relevance and sustainability. The number of regional heads in Areas I, II, and III amounting to 32 regional heads are much higher than that of Area IV amounting to 18 regional heads. This fact shows that there is still a great potential to develop the transformational leadership and to apply the catalytic collaboration to make them much better.

Second, not so many leaders have made a catalytic collaboration. It can be shown from the fact that many leaders are in Area I and Area III, namely 27 regional leaders. In fact, 13 regional heads have not made a catalytic collaboration although their transformational leadership scores are high. It shows that there is a big potential and space to take advantage of the catalytic collaboration so that it can leverage new sources of economic growth in Indonesia. A catalytic collaboration is deemed important to be applied since there is a quite big, different impact between the leaders in Area IV and the leaders in Areas I and III where a catalytic collaboration serves as the confounding factor.

Third, although leaders in general can make a catalytic collaboration, it is highly unlikely that non-transformational leaders will make a catalytic collaboration (Area II). Moreover, the regional heads in Area II will generate sustainable innovation, but it is not relevant to the society's actual needs. Therefore, a catalytic collaboration will create a greater impact if committed by a transformational leader.

Fourth, many regional heads have already come up with relevant solutions (Area III), however, they cannot be implemented for a long term. In many cases, work programs will change due to the changing of the regional heads. This relevant but unsustainable solution may take place due to several factors. The first is a short-term decision made by the regional heads. The second is a situation where the scope of the region is still so narrow, so the regional heads cannot make a very great impact yet. The third is the fact that there are no strategic foresights on the potential collaboration that may take place yet.

\section{Discussion}

The matrix explained above can also give us an understanding on different impacts that the leaders in Areas I, II, III, and IV create. Below are the impacts of the regional heads in general based on the matrix above. In general, the regional heads in Area I experience economic growth; however, no data are showing the relevance between the created impact and the vision and missions / targets that the regions wish to achieve. Only two regions are creating positive impact on the environment (environmental sustainability); therefore, the impacts of innovation of the regional heads in Area I have not met the relevance and sustainability aspects. 
The regional heads in Area II show different impacts from that of Area I. In general, the regional heads in Area II create impacts such as awards that they receive in several sectors due to the increased economic growth in those sectors. Meanwhile, some other regional heads in Area II generate sustainable programs that are in line with the matrix of relevance and sustainability above.

Next, the comparison between the matrix and the collected data might show us the impact that the regional heads in Area III create. The impacts created by the regional heads in Area III seem to be varied. For instance, there are certain different regions with the growing number of tourists, infrastructure development and establishment of the technology-savvy society, and increased farmers' living standards, respectively. Various impacts in those regions might show that the impacts created by those regional heads are already relevant and in accordance with the specific targets of those regions. In general, there are also increased economic indicators in those regions. The thing that does not appear to those regional heads in this area is the sustainability aspect.

The next thing is Area IV. In general, in terms of their impacts, we can conclude that those regional heads in Area IV create quite significant impact on their regions. Similar to the impacts created by the regional heads in Area III, the impacts created by the regional heads in Area IV vary, too. In some regions, they are more infrastructure development and the number of tourists. Meanwhile, in other regions, they are less environmental pollution and potential duplication of innovation that other regions could make. Moreover, there are greater inclusivity and innovation extent. It is recorded that there is sustainable cooperation in the regions belonging to Area IV. Therefore, those things mentioned above show that the regional heads in Area IV have a relevant and sustainable innovation.

In general, by analyzing SIM, we can describe the conditions of regional leadership in Indonesia. The leaders with good transformational leadership competencies who made a catalytic collaboration can generate relevant and sustainable solutions. The analysis is then confirmed by the data that has been collected on the impacts of each region's work programs. There are several impacts such as better infrastructures, increased regional and societal revenues in general, decreased poverty rates, innovations generating a breakthrough, potential innovation duplication, creations of more jobs, meeting several SDGs points, and social, environmental, and economic sustainability.

If we observe the catalytic collaboration components, we find out that a catalytic collaboration can generate more diverse results and greater impacts than that of the initial goals of the program. The data on the regional head samples shows that leaders with good transformational leadership competencies, if supported by a catalytic collaboration in their leadership, have proven to create greater and more sustainable impacts on the regions. Not only do the leaders run their programs well, but they can also make an innovation to achieve the ultimate goals for the sake of their regions.

Innovation and utilization of collaboration with catalytic collaboration components can encourage the transformation sustainability that they conduct. Through the prioritizing learning component, they will create a more relevant solution due to the knowledge sharing among the pertinent parties, so the solutions to the problem will be more right on target. Moreover, its problem identification is deemed to be more relevant since the R\&D data employed to create the solution were available. Next, systems thinking and action will increase the opportunity to 
perceive the challenges and chances from a different perspective. Democratizing access to assets in the collaboration will also encourage it, so this will help the network interconnected and share information more easily and fair, especially with a more rapid technological advancement. Furthermore, the long-term, diverse and transformational relationships nurtured through the catalytic collaboration will touch the sustainability component.

\section{Conclusion}

This study aimed to analyze the role of a catalytic collaboration as a tool to leverage the transformational leadership competencies. The samples of the study (50 regional heads) show a variety both in the transformational leadership aspects and in the catalytic collaboration aspects. Most of the regional heads still do not own those nine transformational leadership competencies. The data mapping and analysis also shows that, in general, many regional heads in Indonesia have not made a catalytic collaboration yet. Most of the regional heads cannot meet all of the catalytic collaboration components. Despite the fact that, most of the regional heads have still not met those two aspects, there are regional heads deemed to be transformational leaders who make a catalytic collaboration.

Based on the Sustainable Innovation Matrix proposed in this study, the transformational leaders who made a catalytic collaboration have proven the ability to create significant impacts on their regions. The leaders with good transformational leadership competencies who make a catalytic collaboration can generate innovations that not only create relevant impacts on the needs of their regions, but they were also sustainable in terms of economic and environmental aspects.

That fact answered the question of the study that a catalytic collaboration can encourage effective transformational leadership in generating sustainable innovation and growth. The innovations that some sample regional heads generated reflect the fact that leaders with good transformational leadership competencies possessed a catalytic collaboration component to show a significant result for their regional development, especially in sustainable development for their regions in many sectors; moreover, the regions make obvious progress. It happens since not only do the innovations that they generate can focus on the person who built it, but they can also collaborate with many parties in order that the programs could be sustainably conducted.

\section{Implication}

Different geographic, demographic, and psychographic conditions of regions in Indonesia show various results in this study. The regional heads have different capabilities depending on their breakthrough and innovation that they can generate. Data distribution in the samples of this study varies especially in the regional heads' efforts to meet the criteria of transformational leadership competencies and catalytic collaboration components and in whether the impacts of their achievements and program that they create are sustainable or not. This uneven distribution shows social and economic gaps among the regions, so the regions located near big cities might have more information than that of secluded areas. However, it is highly likely that regional heads with great transformational leadership competencies will be able to develop and enhance their regions although the regions have limited resources better than regional heads who have 
broader regions. This might happen if those leaders have good transformational leadership competencies, so the programs that they conduct can run well and make significant results.

Therefore, in the context of Indonesia, collaboration has not played an important role in regional development. Many regional heads are still focusing on developing their own regions with the regions' own power and resources including the budgets. However, if these regional heads make a collaboration with various parties that can be involved in the formulation and implementation of the programs, they will be able to create a more comprehensive result and a more sustainable impact since they have already made collaboration with various parties in the process. Later on, if the regional heads are replaced with the newly elected ones, the programs that they have made will still be conducted by the new regional heads in order that the regions will be more developed and make progress. The changing times in the industry 4.0 era are a great opportunity for a leader to formulate a program involving various parties. Various sources of information can easily be accessed; moreover, it becomes faster and more efficient to communicate with others. Therefore, a leader is supposed to be able to take advantage of this digital era well in order to be able to communicate with various parties and to apply the technology when conducting development in this region catalytically.

That a catalytic collaboration is important shows that not only leaders must have good transformational leadership competencies, but they must also make a catalytic collaboration. Those leaders can generate new innovation and breakthroughs for their regions and they will surely create a sustainable impact. Those leaders must dare to make innovation and strongly care for their regional development despite limited resources there. However, those leaders can take an opportunity of this industry 4.0 era or must collaborate with other parties in order that their relatively limited resources that their regions own will become a great opportunity in the future for the progress of the regions that they lead.

Finally, this finding theoretically implies that the sustainable innovation matrix can be a contribution to the science of leadership, especially the relationship between leadership style, collaboration type, and sustainable innovation. Practically, this finding can be an assessment tool for the performance of regional heads in Indonesia.

\section{References}

Bank Indonesia Institute. (2018). Economic leadership for regional government leaders (REL) Angkatan IV: Proceeding. Jakarta: Bank Indonesia.

Boyer-Kassem, T., Mayo-Wilson, C., \& Weisberg, M., (Eds.). (2017). Scientific collaboration and collective knowledge: New essays. New York: Oxford University Press.

Business Directory. (2017). Silo mentality. Retrieved from http://www.businessdictionary.com/definition/ silomentality.html

Dhahir, D. F. (2019). Indonesian Ministry of Communications and Informatics strategic plan for reducing the digital divide. Jurnal Penelitian Komunikasi dan Pembangunan, 20(2), 71-86. http://dx.doi.org/10.31346/jpikom.v20i2.2235

Eckert, V.H. (2017). Collaboration for innovation: Why technology alone isn't enough. PwC Global. Retrieved from https://www.pwc.com/gx/en/ceo-agenda/pwc-at-davos/blogs/2017/collaboration-for-innovation-why-technology-aloneisnt-enough.html 
Edison, R. E., Juhro, S. M., Aulia, A. F., \& Widiasih, P. A. (2019). Transformational leadership and neurofeedback: The medical perspective of neuroleadership. International Journal of Organizational Leadership Forthcoming, 8, 46-62.

Goleman, D., \& Senge, P. (2014). The triple focus: A new approach to education. Florence: More Than Sound Productions.

Gulati, R., \& Sytch, M. (2008). Does familiarity breed trust? Revisiting the antecedents of trust. Managerial Decision and Economics, 29(2-3), 165-190.

Hadiyat, Y. D. (2014). Kesenjangan digital di Indonesia: Studi kasus di Kabupaten Wakatobi [Digital divide in Indonesia: Case study in Wakatobi District]. Jurnal Penelitian Komunikasi dan Pembangunan, 17(2), 81-90. Retrieved from https://jurnal.kominfo.go.id/index.php/pekommas/article/view/1170203

Juhro, S. M. (Ed.). (2019). Transformational leadership: Konsep, pendekatan, dan implikasi pada pembangunan [Transformational leadership: Concepts, approaches, and implications for development]. Jakarta: Bank Indonesia Institute.

Juhro, S. M., \& Aulia, A. F. (2019). New sources of growth: The role of frugal innovation and transformational leadership. Bulletin of Monetary Economics and Banking, 22(3), 383-402.

Juhro, S. M., \& Aulia, A. F. (2018). Transformational leadership through applied neuroscience: Transmission mechanism of the thinking process. International Journal of Organizational Leadership, 7(3) 211-229.

Lai, E.R. (2011). Motivation: A literature review. Pearson Research Report. Retrieved from http://images.pearsonassessments.com/images/tmrs/motivation_review_final.pdf

Maalouf, G. Y. (2018). The effect of collaborative leadership on organizational learning via employees' benefits and innovativeness. Arabian Journal of Business and Management Review, 8(2). 342.

Raghupathi, W., \& Raghupathi, V. (2014). Big data analytics in healthcare: promise and potential. Health Information Science and Systems, 2(3), 1-10.

Riemer, K., Schellhammer, S., \& Meinert, M. (Eds). (2019). Collaboration in the digital age: How technology enables individuals, teams and businesses. Switzerland: Springer International Publishing AG.

Shift Indonesia. (2014). Menghapus dan menghindari silo di internal perusahaan [Removing and avoiding silos within the company]. Retrieved from http://shiftindonesia.com/menghapus-dan-menghindari-silo-di-internal-perusahaan.

Tett, G., (2015). The silo effect: The peril of expertise and the promise of breaking down barriers. New York: Simon and Schuster Paperbacks.

Vanneste, B. S. (2016). From interpersonal to inter-organisational trust: The role of indirect reciprocity. Journal of Trust Research, 6(1), 7-36.

Vayena, E., Dzenowagis, J., \& Langfeld, M. (2016). Evolving health data ecosystem. World Health Organization, http://www.who.int/ehealth/resources/ecosystem/en/

Watson-Manheim, M. B., Chudoba, K. M., \& Crowston, K. (2012). Perceived discontinuities and constructed continuities in virtual work. Information Systems Journal, 22(1), 29-52.

World Economic Forum. (2013). Thriving in a hyperconnected world. Retrieved from https://www.weforum.org/agenda/2013/01/thriving-in-a-hyperconnected-world/

Zaheer, A., \& Harris, J. (2006). Inter-organizational trust. In O. Shenkar \& J. Reuer (Eds.), Handbook of strategic alliances (pp. 169-197). London: Sage.

Zohdy, N., Samali, M., Laidler-Kylander, N., \& Simonin, B. (2016). A catalytic collaboration. Standford Social Innovation Review. Retreived from https://ssir.org/articles/entry/catalytic_collaboration

Zucker, L. G. (1987). Institutional theories of organization. Annual Review of Sociology, 13(1), 443-46. 
Table 1

\section{Appendix}

The Study's Respondent Data

\begin{tabular}{|c|c|c|c|c|c|c|c|c|c|c|c|c|c|c|c|c|c|c|}
\hline $\mathrm{S}$ & \multicolumn{10}{|c|}{$\begin{array}{c}\text { Transformational Leadership } \\
\text { Competencies }\end{array}$} & \multicolumn{5}{|c|}{$\begin{array}{l}\text { Catalytic Collaboration } \\
\text { Components }\end{array}$} & \multirow[b]{2}{*}{ Relevance } & \multirow[b]{2}{*}{ Scalability } & \multirow[b]{2}{*}{ Ultimate Goal } \\
\hline $\begin{array}{l}\mathrm{m} \\
\mathrm{p} \\
\mathrm{l} \\
\mathrm{e}\end{array}$ & $\begin{array}{l}\mathrm{B} \\
\mathrm{r}\end{array}$ & $\begin{array}{l}\mathrm{A} \\
\mathrm{g}\end{array}$ & $\begin{array}{l}\mathrm{E} \\
\mathrm{I}\end{array}$ & $\begin{array}{l}\mathrm{S} \\
\mathrm{I}\end{array}$ & $\begin{array}{l}\text { I } \\
n \\
\text { f }\end{array}$ & $\begin{array}{l}\mathrm{C} \\
\mathrm{o} \\
\mathrm{m}\end{array}$ & $\begin{array}{l}\mathrm{V} \\
\mathrm{i} \\
\mathrm{s}\end{array}$ & $\begin{array}{l}P \\
S\end{array}$ & $\begin{array}{l}\mathrm{D} \\
\mathrm{M}\end{array}$ & $\begin{array}{l}\mathrm{S} \\
\mathrm{k} \\
\mathrm{o} \\
\mathrm{r}\end{array}$ & $\begin{array}{l}\mathrm{P} \\
\mathrm{L}\end{array}$ & $\begin{array}{l}\mathrm{S} \\
\mathrm{T} \\
\mathrm{A}\end{array}$ & $\begin{array}{l}\mathrm{D} \\
\mathrm{A}\end{array}$ & $\mathrm{R}$ & $\begin{array}{l}\mathrm{S} \\
\mathrm{k} \\
\mathrm{o} \\
\mathrm{r}\end{array}$ & & & \\
\hline 1 & & & 1 & 1 & $\checkmark$ & $\checkmark$ & $\checkmark$ & $\sqrt{ }$ & $\checkmark$ & 7 & & & & $\checkmark$ & 1 & $\mathrm{RR}$ & SR & - Various awards \\
\hline 2 & 1 & $\gamma$ & $\gamma$ & $\sqrt{ }$ & $\checkmark$ & $\checkmark$ & $\checkmark$ & $\checkmark$ & $\checkmark$ & 9 & $\checkmark$ & $\checkmark$ & $\checkmark$ & $\checkmark$ & 4 & RT & ST & $\begin{array}{l}\text { - Enhanced infrastructure } \\
\text { - Increased number of } \\
\text { tourists } \\
\text { - Stable economic growth } \\
\text { - Various awards } \\
\end{array}$ \\
\hline 3 & & 1 & 1 & 1 & $\checkmark$ & $\checkmark$ & $\sqrt{ }$ & & & 6 & & $\checkmark$ & $\checkmark$ & $\checkmark$ & 3 & RT & ST & - Various awards \\
\hline 4 & & $\gamma$ & 1 & 1 & $\checkmark$ & $\checkmark$ & $\sqrt{ }$ & & & 6 & $\checkmark$ & $\checkmark$ & $\checkmark$ & $\checkmark$ & 4 & RT & ST & - Various awards \\
\hline 5 & & & & & $\checkmark$ & $\checkmark$ & $\checkmark$ & $\checkmark$ & $\checkmark$ & 5 & $\checkmark$ & & & & 1 & RT & SR & $\begin{array}{l}\text { - Reduced poverty rate } \\
\text { - The provincial } \\
\text { government backup to } \\
\text { develop infrastructure }\end{array}$ \\
\hline 6 & 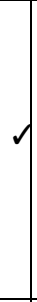 & 1 & 1 & $\gamma$ & $\checkmark$ & $\checkmark$ & $\checkmark$ & $\checkmark$ & $\checkmark$ & 9 & $\checkmark$ & $\checkmark$ & $\sqrt{ }$ & $\checkmark$ & 4 & RT & ST & $\begin{array}{l}\text { - Increased revenue of the } \\
\text { community } \\
\text { - Less environmental } \\
\text { pollution } \\
\text { - Duplication potential in } \\
\text { other regions } \\
\text { - The best innovator award } \\
\text { - Products can reach out } \\
\text { broader market }\end{array}$ \\
\hline 7 & & 1 & 1 & 1 & $\checkmark$ & $\sqrt{ }$ & $\sqrt{ }$ & & & 6 & $\sqrt{ }$ & & $\checkmark$ & & 2 & RT & SR & $\begin{array}{l}\text { Positive responses from } \\
\text { the community }\end{array}$ \\
\hline 8 & 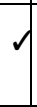 & & 1 & $\gamma$ & $\checkmark$ & $\checkmark$ & $\checkmark$ & & & 6 & $\checkmark$ & & & $\checkmark$ & 2 & RT & ST & $\begin{array}{l}\text { One of the best regions } \\
\text { award } \\
\text { - Controlled inflation }\end{array}$ \\
\hline 9 & & & 1 & $\gamma$ & $\checkmark$ & $\checkmark$ & $\sqrt{ }$ & & & 5 & $\checkmark$ & & & $\checkmark$ & 2 & RT & SR & $\begin{array}{l}\text { - Developments carried out } \\
\text { in several sectors }\end{array}$ \\
\hline $\begin{array}{l}1 \\
0\end{array}$ & $\sqrt{ }$ & $\lambda$ & $\gamma$ & 1 & $\checkmark$ & $\checkmark$ & $\checkmark$ & $\checkmark$ & $\checkmark$ & 9 & $\checkmark$ & & & $\checkmark$ & 2 & RT & ST & $\begin{array}{l}\text { - Development based on } \\
\text { the regional potential } \\
\text { - Cooperation among } \\
\text { various parties } \\
\text { - Various awards } \\
\text { - Accomplishment of } \\
\text { almost main regional } \\
\text { indicators } \\
\end{array}$ \\
\hline $\begin{array}{l}1 \\
1\end{array}$ & & & & & & & $\checkmark$ & & & 1 & $\checkmark$ & & & & 1 & $\mathrm{RR}$ & SR & - Various awards \\
\hline $\begin{array}{l}1 \\
2\end{array}$ & & & $\checkmark$ & 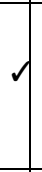 & $\checkmark$ & $\checkmark$ & $\sqrt{ }$ & & & 5 & $\checkmark$ & $\checkmark$ & & & 2 & RT & ST & $\begin{array}{l}\text { - Enhanced Economic } \\
\text { Growth and Human } \\
\text { Development Index } \\
\text { (HDI) } \\
\text { - Various awards }\end{array}$ \\
\hline $\begin{array}{l}1 \\
3\end{array}$ & & & & & & & $\checkmark$ & $\checkmark$ & $\checkmark$ & 3 & & & $\checkmark$ & & 1 & RT & SR & $\begin{array}{l}\text { - Various awards } \\
\text { - Stable economic growth }\end{array}$ \\
\hline $\begin{array}{l}1 \\
4\end{array}$ & & & & & & & $\checkmark$ & & & 1 & & & $\checkmark$ & & 1 & $\mathrm{RR}$ & SR & $\begin{array}{l}\text { - Enhanced Human } \\
\text { Development Index } \\
\text { (IPM) } \\
\text { - Various awards } \\
\end{array}$ \\
\hline $\begin{array}{l}1 \\
5\end{array}$ & & & & & & & $\checkmark$ & $\checkmark$ & $\checkmark$ & 3 & & & $\checkmark$ & & 1 & RT & SR & $\begin{array}{l}\text { - Various awards } \\
\text { - Stable economic growth }\end{array}$ \\
\hline $\begin{array}{l}1 \\
6\end{array}$ & $\checkmark$ & $\gamma$ & $\gamma$ & $\checkmark$ & $\checkmark$ & $\checkmark$ & $\checkmark$ & $\checkmark$ & $\checkmark$ & 9 & $\checkmark$ & $\checkmark$ & $\checkmark$ & $\checkmark$ & 4 & RT & ST & $\begin{array}{l}\text { - Creations of more jobs } \\
\text { - Decreased poverty rate }\end{array}$ \\
\hline
\end{tabular}




\begin{tabular}{|c|c|c|c|c|c|c|c|c|c|c|c|c|c|c|c|c|c|c|}
\hline $\begin{array}{c}S \\
\mathrm{a}\end{array}$ & \multicolumn{10}{|c|}{$\begin{array}{c}\text { Transformational Leadership } \\
\text { Competencies }\end{array}$} & \multicolumn{5}{|c|}{$\begin{array}{l}\text { Catalytic Collaboration } \\
\text { Components }\end{array}$} & \multirow[b]{2}{*}{ Relevance } & \multirow[b]{2}{*}{ Scalability } & \multirow[b]{2}{*}{ Ultimate Goal } \\
\hline $\begin{array}{l}\mathrm{m} \\
\mathrm{p} \\
1 \\
\mathrm{e}\end{array}$ & $\begin{array}{l}\mathrm{B} \\
\mathrm{r}\end{array}$ & $\begin{array}{l}\mathrm{A} \\
\mathrm{g}\end{array}$ & $\begin{array}{l}\mathrm{E} \\
\mathrm{I}\end{array}$ & $\begin{array}{l}\mathrm{S} \\
\mathrm{I}\end{array}$ & $\begin{array}{l}I \\
\text { n } \\
f\end{array}$ & $\begin{array}{l}\mathrm{C} \\
\mathrm{o} \\
\mathrm{m}\end{array}$ & $\begin{array}{l}\text { V } \\
i \\
\text { S }\end{array}$ & $\begin{array}{l}P \\
S\end{array}$ & $\begin{array}{l}\mathrm{D} \\
\mathrm{M}\end{array}$ & $\begin{array}{l}\mathrm{S} \\
\mathrm{k} \\
\mathrm{o} \\
\mathrm{r}\end{array}$ & $\begin{array}{l}\mathrm{P} \\
\mathrm{L}\end{array}$ & $\begin{array}{l}\mathrm{S} \\
\mathrm{T} \\
\mathrm{A}\end{array}$ & $\begin{array}{l}\mathrm{D} \\
\mathrm{A}\end{array}$ & $\mathrm{R}$ & $\begin{array}{l}\mathrm{S} \\
\mathrm{k} \\
\mathrm{o} \\
\mathrm{r}\end{array}$ & & & \\
\hline $\begin{array}{l}1 \\
7\end{array}$ & & 1 & $\gamma$ & $\sqrt{ }$ & $\checkmark$ & $\checkmark$ & $\sqrt{ }$ & & & 6 & $\checkmark$ & & $\sqrt{ }$ & & 2 & RT & ST & - Various awards \\
\hline $\begin{array}{l}1 \\
8\end{array}$ & & & & & & & $\checkmark$ & & $\checkmark$ & 2 & $\checkmark$ & & $\sqrt{ }$ & & 2 & RR & SR & $\begin{array}{l}\text { - Decreased number of } \\
\text { poor people } \\
\text { - Decreased } \\
\text { unemployment rate } \\
\text { - Increased HDI } \\
\text { - Several awards received } \\
\text { by the regional } \\
\text { government } \\
\end{array}$ \\
\hline $\begin{array}{l}1 \\
9\end{array}$ & & 1 & & & & & $\checkmark$ & & & 2 & & & $\sqrt{ }$ & & 1 & $\mathrm{RR}$ & SR & $\begin{array}{l}\text { Enhanced economic } \\
\text { growth } \\
\text { - Various awards }\end{array}$ \\
\hline $\begin{array}{l}2 \\
0\end{array}$ & $\gamma$ & $\gamma$ & $\gamma$ & 1 & $\checkmark$ & $\checkmark$ & $\sqrt{ }$ & $\sqrt{ }$ & $\checkmark$ & 9 & & & $\sqrt{ }$ & & 1 & RT & SR & $\begin{array}{l}\text { - Increased productivity } \\
\text { - Opened access } \\
\text { - Various awards }\end{array}$ \\
\hline $\begin{array}{l}2 \\
1\end{array}$ & & & $\gamma$ & $\gamma$ & $\checkmark$ & $\checkmark$ & $\checkmark$ & & & 5 & $\checkmark$ & & & & 1 & RT & ST & - Social inclusion \\
\hline $\begin{array}{l}2 \\
2\end{array}$ & $\gamma$ & 1 & & & & & $\sqrt{ }$ & & & 3 & $\checkmark$ & & $\sqrt{ }$ & & 2 & $\mathrm{RR}$ & SR & $\begin{array}{l}\text { - Various awards } \\
\text { - Environmental awareness } \\
\text { on the people }\end{array}$ \\
\hline $\begin{array}{l}2 \\
3\end{array}$ & & & $\gamma$ & $\gamma$ & $\checkmark$ & $\checkmark$ & $\sqrt{ }$ & & & 5 & $\checkmark$ & & & $\checkmark$ & 2 & $\mathrm{RR}$ & ST & $\begin{array}{l}\text { - Increased Gross Regional } \\
\text { Domestic Product } \\
\text { - Regional economic } \\
\text { growth is greater than } \\
\text { national economic } \\
\text { growth } \\
\text { - Equitable development }\end{array}$ \\
\hline $\begin{array}{l}2 \\
4\end{array}$ & & & $\gamma$ & 1 & $\checkmark$ & $\checkmark$ & $\checkmark$ & $\sqrt{ }$ & $\checkmark$ & 7 & & & $\checkmark$ & & 1 & RT & ST & $\begin{array}{l}\text { Growing number of } \\
\text { tourists } \\
\text { - Growing number of } \\
\text { SMEs } \\
\text { - Various awards }\end{array}$ \\
\hline $\begin{array}{l}2 \\
5\end{array}$ & $\gamma$ & $\gamma$ & & & $\checkmark$ & $\checkmark$ & $\checkmark$ & & & 5 & & & $\checkmark$ & & 1 & RR & SR & $\begin{array}{l}\text { - Better known batik from } \\
\text { the region }\end{array}$ \\
\hline $\begin{array}{l}2 \\
6\end{array}$ & 1 & $\gamma$ & $\gamma$ & $\gamma$ & $\checkmark$ & $\checkmark$ & $\sqrt{ }$ & $\sqrt{ }$ & $\checkmark$ & 9 & $\checkmark$ & $\checkmark$ & $\sqrt{ }$ & $\checkmark$ & 4 & RT & ST & $\begin{array}{l}\text { - Increased number on the } \\
\text { indicators of human } \\
\text { development and } \\
\text { economic growth } \\
\text { - Sustainable collaboration } \\
\text { - Award on sustainable } \\
\text { city }\end{array}$ \\
\hline $\begin{array}{l}2 \\
7\end{array}$ & $\gamma$ & & & & $\checkmark$ & $\checkmark$ & & $\sqrt{ }$ & $\checkmark$ & 4 & & & $\sqrt{ }$ & & 1 & $\mathrm{RR}$ & SR & $\begin{array}{l}\text { - Social inclusion } \\
\text { - Award on environmental } \\
\text { aspect }\end{array}$ \\
\hline $\begin{array}{l}2 \\
8\end{array}$ & $\lambda$ & & 1 & & $\checkmark$ & $\checkmark$ & $\checkmark$ & $\checkmark$ & $\checkmark$ & 6 & & & $\checkmark$ & & 1 & $\mathrm{RR}$ & SR & $\begin{array}{l}\text { Increased number on } \\
\text { health programs } \\
\text { - Equitable village } \\
\text { development assistance }\end{array}$ \\
\hline $\begin{array}{l}2 \\
9\end{array}$ & & & & $\gamma$ & & $\checkmark$ & & & & 2 & & & & $\checkmark$ & 1 & $\mathrm{RR}$ & SR & $\begin{array}{l}\text { - Award on environmental } \\
\text { aspect } \\
\text { - Social involvement in the } \\
\text { society }\end{array}$ \\
\hline $\begin{array}{l}3 \\
0\end{array}$ & & 1 & $\gamma$ & $\gamma$ & $\checkmark$ & $\checkmark$ & $\checkmark$ & $\checkmark$ & $\checkmark$ & 8 & & & $\checkmark$ & $\checkmark$ & 2 & RT & SR & $\begin{array}{l}\text { - Welfare of farmers' } \\
\text { commodities } \\
\text { - Social involvement in the } \\
\text { community and } \\
\text { sustainable collaboration } \\
\text { - Various awards }\end{array}$ \\
\hline
\end{tabular}




\begin{tabular}{|c|c|c|c|c|c|c|c|c|c|c|c|c|c|c|c|c|c|c|}
\hline $\begin{array}{l}S \\
\mathrm{~s}\end{array}$ & \multicolumn{10}{|c|}{$\begin{array}{c}\text { Transformational Leadership } \\
\text { Competencies }\end{array}$} & \multicolumn{5}{|c|}{$\begin{array}{l}\text { Catalytic Collaboration } \\
\text { Components }\end{array}$} & \multirow[b]{2}{*}{ Relevance } & \multirow[b]{2}{*}{ Scalability } & \multirow[b]{2}{*}{ Ultimate Goal } \\
\hline $\begin{array}{l}\mathrm{m} \\
\mathrm{p} \\
1 \\
\mathrm{e}\end{array}$ & $\begin{array}{l}\mathrm{B} \\
\mathrm{r}\end{array}$ & $\begin{array}{l}\mathrm{A} \\
\mathrm{g}\end{array}$ & $\begin{array}{l}\mathrm{E} \\
\mathrm{I}\end{array}$ & $\begin{array}{l}S \\
I\end{array}$ & $\begin{array}{l}\text { I } \\
n \\
f\end{array}$ & $\begin{array}{l}\mathrm{C} \\
\mathrm{o} \\
\mathrm{m}\end{array}$ & $\begin{array}{l}\text { V } \\
i \\
\text { S }\end{array}$ & $\begin{array}{l}P \\
S\end{array}$ & $\begin{array}{l}\mathrm{D} \\
\mathrm{M}\end{array}$ & $\begin{array}{l}\mathrm{S} \\
\mathrm{k} \\
\mathrm{o} \\
\mathrm{r}\end{array}$ & $\begin{array}{l}\mathrm{P} \\
\mathrm{L}\end{array}$ & $\begin{array}{l}\mathrm{S} \\
\mathrm{T} \\
\mathrm{A}\end{array}$ & $\begin{array}{l}\mathrm{D} \\
\mathrm{A}\end{array}$ & $\mathrm{R}$ & $\begin{array}{l}\mathrm{S} \\
\mathrm{k} \\
\mathrm{o} \\
\mathrm{r}\end{array}$ & & & \\
\hline $\begin{array}{l}3 \\
1\end{array}$ & & & $\lambda$ & 1 & $\checkmark$ & $\checkmark$ & & & & 4 & & $\checkmark$ & & & 1 & $\mathrm{RR}$ & SR & $\begin{array}{l}\text { - Increased HR quality } \\
\text { - Sustainable collaboration }\end{array}$ \\
\hline $\begin{array}{l}3 \\
2\end{array}$ & $\gamma$ & $\gamma$ & $\checkmark$ & $\gamma$ & $\checkmark$ & $\checkmark$ & $\checkmark$ & $\checkmark$ & $\checkmark$ & 9 & $\checkmark$ & $\checkmark$ & $\checkmark$ & $\checkmark$ & 4 & RT & ST & $\begin{array}{l}\text { - Improvement on the } \\
\text { quality of life of the } \\
\text { people } \\
\text { - High level of trust from } \\
\text { the society } \\
\text { - Decreased number of } \\
\text { poverty and increased } \\
\text { number of regional } \\
\text { income }\end{array}$ \\
\hline $\begin{array}{l}3 \\
3\end{array}$ & $\gamma$ & $\gamma$ & & 1 & $\checkmark$ & $\checkmark$ & $\checkmark$ & & & 6 & & $\checkmark$ & & & 1 & RT & SR & $\begin{array}{l}\text { - Environmental and } \\
\text { technological awareness }\end{array}$ \\
\hline $\begin{array}{l}3 \\
4\end{array}$ & $\gamma$ & $\gamma$ & & & & $\checkmark$ & & $\checkmark$ & $\checkmark$ & 5 & & & & $\checkmark$ & 1 & RT & SR & $\begin{array}{l}\text { - Collaboration with other } \\
\text { parties } \\
\text { - Better quality on the } \\
\text { trade sector }\end{array}$ \\
\hline $\begin{array}{l}3 \\
5\end{array}$ & 1 & $\gamma$ & $\sqrt{ }$ & $\gamma$ & $\checkmark$ & $\checkmark$ & $\checkmark$ & $\checkmark$ & $\checkmark$ & 9 & $\checkmark$ & $\checkmark$ & $\checkmark$ & $\checkmark$ & 4 & RT & ST & $\begin{array}{l}\text { - Improvement on the } \\
\text { regional income as well } \\
\text { as the society } \\
\text { - Sustainable programs }\end{array}$ \\
\hline $\begin{array}{l}3 \\
6\end{array}$ & & & $\lambda$ & 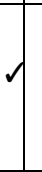 & $\checkmark$ & $\checkmark$ & $\checkmark$ & $\checkmark$ & & 6 & & & & $\checkmark$ & 1 & RT & SR & $\begin{array}{l}\text { - Decreased number on } \\
\text { poverty } \\
\text { - Increased number on } \\
\text { employment } \\
\text { - Various awards }\end{array}$ \\
\hline $\begin{array}{l}3 \\
7\end{array}$ & $\gamma$ & $\gamma$ & $\lambda$ & $\gamma$ & $\checkmark$ & $\checkmark$ & $\sqrt{ }$ & $\sqrt{ }$ & $\checkmark$ & 9 & $\checkmark$ & & & $\checkmark$ & 2 & RT & ST & $\begin{array}{l}\text { - Became a pilot program } \\
\text { for another regions } \\
\text { - Sustainable collaboration }\end{array}$ \\
\hline $\begin{array}{l}3 \\
8\end{array}$ & & 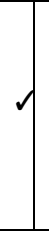 & & & $\checkmark$ & $\checkmark$ & $\checkmark$ & $\checkmark$ & $\checkmark$ & 6 & & & & $\checkmark$ & 1 & RT & ST & $\begin{array}{l}\text { - Opened access as an } \\
\text { impact from the } \\
\text { infrastructure } \\
\text { development } \\
\text { - Collaboration on } \\
\text { increasing the quality of } \\
\text { education }\end{array}$ \\
\hline $\begin{array}{l}3 \\
9\end{array}$ & & $\lambda$ & $d$ & $\gamma$ & $\checkmark$ & $\checkmark$ & $\checkmark$ & & $\checkmark$ & 7 & $\checkmark$ & & $\checkmark$ & $\checkmark$ & 3 & RT & ST & $\begin{array}{l}\text { - Social involvement from } \\
\text { the society } \\
\text { - Various awards }\end{array}$ \\
\hline $\begin{array}{l}4 \\
0\end{array}$ & 1 & 1 & $\lambda$ & 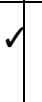 & $\checkmark$ & $\checkmark$ & $\checkmark$ & $\checkmark$ & $\checkmark$ & 9 & $\checkmark$ & & & $\checkmark$ & 2 & RT & ST & $\begin{array}{l}\text { - Sustainable collaboration } \\
\text { - Better condition of the } \\
\text { society }\end{array}$ \\
\hline $\begin{array}{l}4 \\
1\end{array}$ & & 1 & & $\gamma$ & $\checkmark$ & $\checkmark$ & $\checkmark$ & & & 5 & & & & $\checkmark$ & 1 & RT & ST & $\begin{array}{l}\text { - Economic growth } \\
\text { - Sustainable collaboration }\end{array}$ \\
\hline $\begin{array}{l}4 \\
2\end{array}$ & $\gamma$ & $\gamma$ & 1 & $\gamma$ & $\checkmark$ & $\checkmark$ & $\checkmark$ & $\sqrt{ }$ & $\checkmark$ & 9 & $\checkmark$ & $\checkmark$ & $\checkmark$ & $\checkmark$ & 4 & RT & ST & $\begin{array}{l}\text { - Economic growth } \\
\text { - Sustainable programs }\end{array}$ \\
\hline $\begin{array}{l}4 \\
3\end{array}$ & & & $\lambda$ & $\gamma$ & $\checkmark$ & $\checkmark$ & $\checkmark$ & $\checkmark$ & $\checkmark$ & 7 & & & $\checkmark$ & & 1 & RT & ST & $\begin{array}{l}\text { - Various awards } \\
\text { - Collaboration on } \\
\text { increasing the education } \\
\text { quality } \\
\end{array}$ \\
\hline $\begin{array}{l}4 \\
4\end{array}$ & $\gamma$ & & 1 & & $\checkmark$ & $\checkmark$ & $\checkmark$ & $\sqrt{ }$ & $\checkmark$ & 8 & $\checkmark$ & $\checkmark$ & $\checkmark$ & $\checkmark$ & 4 & RT & ST & $\begin{array}{l}\text { - Increased productivity \& } \\
\text { farmers' income } \\
\text { - Decreased poverty }\end{array}$ \\
\hline $\begin{array}{l}4 \\
5\end{array}$ & $\gamma$ & & 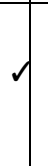 & & $\checkmark$ & $\checkmark$ & $\checkmark$ & & $\checkmark$ & 7 & $\checkmark$ & & $\checkmark$ & $\checkmark$ & 3 & RT & ST & $\begin{array}{l}\text { - Better quality on health, } \\
\text { agriculture, trade, and } \\
\text { education sector } \\
\text { - Better quality of vital } \\
\text { sectors }\end{array}$ \\
\hline
\end{tabular}




\begin{tabular}{|c|c|c|c|c|c|c|c|c|c|c|c|c|c|c|c|c|c|c|}
\hline$S$ & \multicolumn{10}{|c|}{$\begin{array}{l}\text { Transformational Leadership } \\
\text { Competencies }\end{array}$} & \multicolumn{5}{|c|}{$\begin{array}{l}\text { Catalytic Collaboration } \\
\text { Components }\end{array}$} & \multirow[b]{2}{*}{ Relevance } & \multirow[b]{2}{*}{ Scalability } & \multirow[b]{2}{*}{ Ultimate Goal } \\
\hline $\begin{array}{l}\mathrm{m} \\
\mathrm{p} \\
1 \\
\mathrm{e}\end{array}$ & $\begin{array}{l}\mathrm{B} \\
\mathrm{r}\end{array}$ & $\begin{array}{l}\mathrm{A} \\
\mathrm{g}\end{array}$ & $\begin{array}{l}\mathrm{E} \\
\mathrm{I}\end{array}$ & $\begin{array}{l}\mathrm{S} \\
\mathrm{I}\end{array}$ & $\begin{array}{l}I \\
\text { n } \\
f\end{array}$ & $\begin{array}{l}\mathrm{C} \\
\mathrm{o} \\
\mathrm{m}\end{array}$ & $\begin{array}{l}\mathrm{V} \\
\mathrm{i} \\
\mathrm{s}\end{array}$ & $\begin{array}{l}P \\
S\end{array}$ & $\begin{array}{l}\mathrm{D} \\
\mathrm{M}\end{array}$ & $\begin{array}{l}\mathrm{S} \\
\mathrm{k} \\
\mathrm{o} \\
\mathrm{r}\end{array}$ & $\begin{array}{l}\mathrm{P} \\
\mathrm{L}\end{array}$ & $\begin{array}{l}\text { S } \\
\text { T } \\
\mathrm{A}\end{array}$ & $\begin{array}{l}\mathrm{D} \\
\mathrm{A}\end{array}$ & $\mathrm{R}$ & $\begin{array}{l}\mathrm{S} \\
\mathrm{k} \\
\mathrm{o} \\
\mathrm{r}\end{array}$ & & & \\
\hline $\begin{array}{l}4 \\
6\end{array}$ & 1 & $\gamma$ & $\gamma$ & $\gamma$ & $\checkmark$ & $\checkmark$ & $\checkmark$ & $\checkmark$ & $\checkmark$ & 9 & $\checkmark$ & & $\sqrt{ }$ & $\checkmark$ & 3 & RT & ST & $\begin{array}{l}\text { - Sustainable impact } \\
\text { - Increased number of } \\
\text { tourists }\end{array}$ \\
\hline $\begin{array}{l}4 \\
7\end{array}$ & 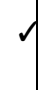 & & & & & & $\checkmark$ & $\sqrt{ }$ & $\checkmark$ & 4 & $\checkmark$ & & $\sqrt{ }$ & $\checkmark$ & 3 & RT & ST & $\begin{array}{l}\text { - Economic independency } \\
\text { - Economic growth }\end{array}$ \\
\hline $\begin{array}{l}4 \\
8\end{array}$ & & $\gamma$ & $\gamma$ & $\gamma$ & $\checkmark$ & $\checkmark$ & & & & 5 & & & $\sqrt{ }$ & $\checkmark$ & 2 & RR & ST & $\begin{array}{l}\text { - Various awards } \\
\text { - Sustainable programs }\end{array}$ \\
\hline $\begin{array}{l}4 \\
9\end{array}$ & & $\sqrt{ }$ & $\gamma$ & $\gamma$ & $\checkmark$ & $\checkmark$ & $\checkmark$ & & & 6 & $\checkmark$ & $\checkmark$ & $\checkmark$ & $\checkmark$ & 4 & RT & ST & $\begin{array}{l}\text { - Various awards } \\
\text { - SDGs number } 3,7 \text {, and } \\
11\end{array}$ \\
\hline $\begin{array}{l}5 \\
0\end{array}$ & $\gamma$ & $\gamma$ & $\gamma$ & $\gamma$ & $\checkmark$ & $\checkmark$ & $\checkmark$ & & & 7 & $\checkmark$ & & $\checkmark$ & & 2 & RT & ST & $\begin{array}{l}\text { - Various awards } \\
\text { - Sustainable collaboration } \\
\text { - Better HR quality } \\
\text { - Social inclusion }\end{array}$ \\
\hline
\end{tabular}

\section{Glossary:}

1. Transformational Leadership Competences

1) $\mathrm{Br}:$ Breakthrough

2) Ag: Agility

3) EI : Emotional Intelligence

4) SI : Social Intelligence

5) Inf : Influencing Skill

6) Com : Communication Skill

7) Vis : Visionary

8) PS : Problem Solving

9) DM : Decision Making
2. Catalytic collaboration components

1) PL : Prioritizing learning

2) STA : Systems thinking \& acting

3) DA : Democratizing access to assets

4) R : Building long-term, diverse, \& transformational relationshipss

3. Relevance \& Scalability

1) RR : Low relevance

2) RT : High relevance

3) SR : Low scalability

4) ST : High scalability 